\title{
BIODIVERSITY OF RHIZOBIA ASSOCIATED WITH COWPEA CULTIVARS IN SOILS OF THE LOWER HALF OF THE SÃO FRANCISCO RIVER VALLEY(1)
}

\author{
Jakson Leite ${ }^{(2)}$, Sirando Lima Seido ${ }^{(3)}$, Samuel Ribeiro Passos ${ }^{(2)}$, Gustavo Ribeiro \\ Xavier $^{(4)}$, Norma Gouvêa Rumjanek ${ }^{(4)} \&$ Lindete Míria Vieira Martins $^{(5)}$
}

\begin{abstract}
The biodiversity of rhizobium in soils of the São Francisco Valley is unknown and can be studied using cowpea as trap plants. The objective of this study was to verify the diversity of diazotrophic bacteria that nodulate cowpea in soils of the lower half of the São Francisco River Valley by morphological and genotypic characterization. Seven soil samples (A1, A2, A3, A4, C1, C2 and MC) were collected to capture bacteria associated to five cowpea cultivars (IPA 206, BRS Pujante, BRS Marataoã, Canapu Roxo, and Sempre Verde), in a $5 \times 7$ factorial design with three replications. Thirty days after plant emergence, the nodules were collected and the bacteria isolated and analyzed in relation to their growth characteristics in YMA medium. The 581 isolates were grouped in 49 morphologic groups. Of this total, $62.3 \%$ formed colonies in up to three days, $33.4 \%$ grew from the $6^{\text {th }}$ day on, and $4.3 \%$ began to grow 4 to 5 days after incubation. Regarding the formation of acids and alkalis, $63 \%$ acidified the medium, $12 \%$ made it alkaline and $25 \%$ maintained the medium at neutral $\mathrm{pH}$. The highest diversity was observed in the A3 sample and in isolates associated with the cultivars Canapu Roxo and BRS Pujante. Thirty-eight representative isolates were chosen for the genotypic characterization, clustered in four groups based on the restriction analysis of $16 \mathrm{~s}$ rDNA. This grouping was strongly correlated with the sampling site; 13 rhizobium isolates had an electrophoretic profile distinct from the standard rhizobium strains used in this study.
\end{abstract}

Index terms: ARDRA, biological nitrogen fixation, Vigna unguiculata.

\footnotetext{
(1) Trabalho desenvolvido no programa RENORBIO (Rede Nordeste de Biotecnologia). Recebido para publicação em novembro de 2008 e aprovado em maio de 2009.

(2) Mestrando em Agronomia - Ciência do Solo, Departamento de Agronomia e Ciência do Solo, Universidade Federal Rural do Rio de Janeiro - UFRRJ. Rod BR 465, Km 7, CEP 23890-000 Seropédica (RJ). E-mail: leitejk@yahoo.com.br; passos.samuel@gmail.com

(3) Mestrando em Agronomia - Horticultura Irrigada, Departamento de Tecnologia e Ciências Sociais, Universidade do Estado da Bahia - UNEB. Av. Edgard Chastinet s/n, Bairro São Geraldo, CEP 48900-000 Juazeiro (BA). E-mails: siroseido@hotmail.com

(4) Embrapa Agrobiologia, BR 465, Km 7, CEP 23890-000 Seropédica (RJ). E-mails: ustavo@cnpab.embrapa.br; norma@cnpab.embrapa.br

(5) Professora do Departamento de Tecnologia e Ciências Sociais, UNEB. E-mail: lmvmartins@uneb.br
} 


\title{
RESUMO: BIODIVERSIDADE DE RIZÓBIO ASSOCIADO A CULTIVARES DE FEIJÃO-CAUPI EM SOLOS DO SUBMÉDIO DO VALE DO SÃO FRANCISCO
}

\begin{abstract}
A biodiversidade de rizóbio de solos do Vale do São Francisco é desconhecida e pode ser estudada utilizando feijão-caupi como planta-isca. Este trabalho teve por objetivo verificar a diversidade de bactérias diazotróficas que nodulam feijão-caupi em solos do Submédio do Vale do São Francisco por meio da caracterização morfológica e genotípica. Sete amostras de solos (A1, A2, A3, A4, C1, C2 e MC) foram coletadas para a captura de bactérias, utilizando cinco cultivares de feijão-caupi (IPA 206, BRS Pujante, BRS Marataoã, Canapu Roxo e Sempre Verde), perfazendo um fatorial $5 \times 7$ com três repetições. Aos 30 dias após a emergência das plantas, os nódulos foram coletados e as bactérias isoladas e analisadas quanto às características culturais em meio YMA. Foram obtidos 581 isolados, que se agruparam em 49 grupos morfológicos. Desse total, 62,3\% formaram colônias em até três dias, 33,4\% cresceram a partir do sexto dia e 4,3\% cresceram entre quatro e cinco dias após a incubação. Quanto à formação de ácido e álcalis, $63 \%$ acidificaram o meio de cultura, $12 \%$ alcalinizarame $25 \%$ mantiveram o $\mathrm{pH}$ do meio neutro. As maiores diversidades foram encontradas nas amostras A3 e nos isolados associados às cultivares Canapu Roxo e BRS Pujante. Escolheram-se 38 isolados representativos para a caracterização genotípica, em que foram obtidos quatro grupos a partir da análise de restrição do $16 s$ rDNA. Este agrupamento teve forte correlação com o local de origem dos isolados, mostrando 13 deles com perfil eletroforético distinto das estirpespadrão de rizóbios utilizadas no estudo.
\end{abstract}

Termos de indexação: ARDRA, fixação biológica de nitrogênio, Vigna unguiculata.

\section{INTRODUCTION}

The symbiosis between leguminous plants such as cowpea [Vigna unguiculata (L.) Walp], and $\mathrm{N}_{2}$ fixing bacteria that form nodules (Rhizobium group) in the soil, is a biological phenomenon that needs to be maximized in agricultural systems. The association with microorganisms supplies plants with $\mathrm{N}$ in a readily assimilable form and in sufficient quantity to make mineral-N fertilization unnecessary. Nitrogen is the key element to stimulate common bean growth and grain yield.

The diversity of rhizobium species, along with the variable edaphoclimatic conditions and the genetic specificities of cowpea varieties, among other factors, make these bacteria more or less effective for biological $\mathrm{N}_{2}$ fixation (BNF). The rhizobial population that nodulates Phaseolus vulgaris was studied by Anyango et al. (1995), in two soils in Kenya (Africa), and this population seemed to be similar in number and $\mathrm{N}_{2}$ fixation effectiveness, but the composition differed.

According to Martins et al. (2003), the rhizobial population in the soil can be extremely variable, both in the composition and the symbiotic characteristics of a species. Furthermore, native and inefficient rhizobium strains can compete with efficient ones, introduced by inoculation, for sites of infection on the host plant roots. Nodules formed by different strains and even by different species may occur in the same plant (Moreira \& Siqueira, 2006).
Cowpea is one of the main products of family farming in the Brazilian semi-arid region, and is especially important as protein source for the lowincome population of rural areas, since it is also resistant to drought and water stress. Nevertheless, there are serious production problems due to the scanty technological resources of the agricultural systems. In drought periods, the limited supply of cowpea, consumed mostly by the poorer population, lowers the nutritional standards (Freire Filho et al., 2005).

Studies that optimize BNF of this crop create conditions for greater cowpea yields and may increase the food security of families. The current management standards of biological and environmental resources have a considerable negative impact on the biological diversity and may seriously and irreversibly undermine the ecological basis that could be conserved by a new development model for this region with sustainable technologies for the efficient use of inoculants in BNF (Martins et al., 2003).

Microbial diversity involves a variety of species in an ecosystem, as well as the intraspecific genetic variation, underlying the functioning of agricultural activities. Soil microorganisms play an important role of great economic and environmental importance in the decomposition of organic matter and nutrient cycling of agro-ecosystems (Figueiredo et al., 2008). The conservation and proper use of this biological resource are essential to maintain sustainability. 
This study aimed at characterizing the morphological and genotypic diversity of rhizobium isolates from soil samples collected along the lower half of the São Francisco river valley using five cowpea cultivars.

\section{MATERIAL AND METHODS}

\section{Sampling sites and soils}

Soil samples were collected in the States of Bahia and Pernambuco, in the region of the lower half of the São Francisco river valley. Each sample consisted of 15 sub-samples collected at a depth of $0-15 \mathrm{~cm}$ in zigzag in an area not exceeding 2 ha. The areas were identified according to the land use system (LUS) namely: A - crop area; $\mathrm{C}$ - native vegetation (caatinga) and $\mathrm{MC}$ - river side vegetation along the São Francisco (Table 1).

\section{Rhizobium capture}

An experiment was performed to trap rhizobium in a greenhouse of the Department of Technology and Social Sciences at the Universidade do Estado da Bahia. For this, soil samples were sieved and distributed in $5 \mathrm{~L}$ polyethylene pots (filled with $3 \mathrm{~kg}$ of soil). From each sample, $1 \mathrm{~kg}$ was separated to determine soil fertility properties (Embrapa, 1997) (Table 2). Four cowpea seeds were sown as trap plants, and thinned to two plants per pot eight days after emergence. Each pot represented one experimental unit. The experiment had a completely randomized, 7 x 5 factorial design: seven soil samples and five cowpea cultivars (IPA 206, BRS Pujante, BRS
Table 2. Chemical characteristics of soil samples from the lower half of the São Francisco river valley

\begin{tabular}{|c|c|c|c|c|c|c|c|}
\hline Sample & MO & $\mathbf{p H}$ & $\mathbf{P}$ & $\mathbf{K}$ & $\mathrm{Ca}$ & Mg & $\mathrm{Na}$ \\
\hline & $\mathrm{g} \mathrm{kg}^{-1}$ & & $\mathrm{mg} \mathrm{dm} \mathrm{m}^{-3}$ & 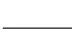 & \multicolumn{2}{|c|}{$-\mathrm{cmol}_{\mathrm{c}} \mathrm{dm}^{-3}$} & \\
\hline $\mathrm{A} 1$ & 28.31 & 6.8 & 7 & 0.27 & 2.1 & 0.8 & 0.02 \\
\hline $\mathrm{A} 2$ & 32.50 & 6.6 & 5 & 0.32 & 2.4 & 1.1 & 0.03 \\
\hline A3 & 28.31 & 8.0 & 13 & 0.44 & 17 & 4.1 & 0.4 \\
\hline $\mathrm{A} 4$ & 19.10 & 7.2 & 31 & 0.43 & 2.8 & 1.5 & 0.26 \\
\hline $\mathrm{C} 1$ & 11.01 & 6.0 & 4 & 0.2 & 2 & 0.7 & 0.04 \\
\hline $\mathrm{C} 2$ & 29.36 & 6.7 & 21 & 0.47 & 4 & 1.3 & 0.03 \\
\hline $\mathrm{MC}$ & 12.82 & 6.3 & 48 & 0.27 & 1.6 & 0.4 & 0.02 \\
\hline
\end{tabular}

Marataoã, Canapu Roxo, and Sempre Verde) with three replications. The pots were irrigated as necessary and harvested 35 days after emergence. The roots were separated from the shoots, washed and the nodules detached, counted and stored in glass bottles with silica gel for subsequent isolation of rhizobia.

\section{Isolation, characterization and grouping}

Rhizobium was isolated soon after counting and storing the nodules. Five nodules from each replication were selected, totaling 15 nodules isolated per treatment. They were rehydrated in distilled water for $40 \mathrm{~min}$ and disinfected in $70 \%$ alcohol for $1 \mathrm{~min}$, $2 \%$ sodium hypochlorite for $30 \mathrm{~s}$ and eight successive washes in sterile water. The disinfested nodules were ground and streaked onto plates with YMA culture

Table 1. Location and characteristics of the areas sampled in two municipalities of the lower half of the São Francisco river valley

\begin{tabular}{|c|c|c|c|}
\hline Area & Characteristic & Site & $\begin{array}{l}\text { Latitude and } \\
\text { longitude }\end{array}$ \\
\hline A1 & $\begin{array}{l}\text { Cultivated with cowpea [Vigna unguiculata (L.) Walp] and mammon } \\
\text { (Ricinus communis L.). }\end{array}$ & Petrolina PE & $\begin{array}{rrr}9^{\circ} 23^{\prime} & 55^{\prime \prime} & \mathrm{S} \\
40^{\circ} 30^{\prime} 03^{\prime \prime} & \mathrm{W}\end{array}$ \\
\hline A2 & Cowpea [Vigna unguiculata (L.) Walp] cultivated in ebb tide. & Petrolina PE & $\begin{aligned} 9^{\circ} 23^{\prime} 55^{\prime \prime} & \mathrm{S} \\
40^{\circ} 30^{\prime} 03^{\prime \prime} & \mathrm{W}\end{aligned}$ \\
\hline A3 & Organic maize cultivation (Zea mays L.) with cowpea [Vigna unguiculada (L.) Walp]. & Juazeiro BA & $\begin{array}{cc}9^{\circ} 24^{\prime} 42^{\prime \prime} & \mathrm{S} \\
40^{\circ} 29^{\prime} 55^{\prime \prime} & \mathrm{W}\end{array}$ \\
\hline A4 & $\begin{array}{l}\text { Irrigated cultivation of Barbados cherry (Malpighia glabra L.) preceded of peanuts } \\
\text { (Arachis hypogaea L.) and cowpea [Vigna unguiculata (L.) Walp]. }\end{array}$ & Petrolina PE & $\begin{array}{ccc}9^{\circ} 23^{\prime} 55^{\prime \prime} & \mathrm{S} \\
40^{\circ} 30^{\prime} & 03^{\prime \prime} & \mathrm{W}\end{array}$ \\
\hline $\mathrm{C} 1$ & $\begin{array}{l}\text { Native vegetation (Caatinga) with predominance of jojoba (Simmondsia chinensis) } \\
\text { and Cnidosculus quercifolius }\end{array}$ & Petrolina PE & 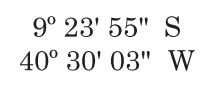 \\
\hline $\mathrm{C} 2$ & $\begin{array}{l}\text { Area of preservation with predominance of vatingueira hay (Caesalpinea bracteosa); } \\
\text { presence of grass and cactus. }\end{array}$ & Juazeiro BA & $\begin{array}{rlll}9^{\circ} 24^{\prime} 42^{\prime \prime} & \mathrm{S} \\
40^{\circ} 29^{\prime} 55^{\prime \prime} & \mathrm{W}\end{array}$ \\
\hline $\mathrm{MC}$ & $\begin{array}{l}\text { Ciliary forest not much dense and diversified in species of the right margin of the } \\
\text { São Francisco River with litter not much dense in reserve area of the Bahia } \\
\text { State University - UNEB. }\end{array}$ & Juazeiro BA & $\begin{array}{rll}9^{\circ} 24^{\prime} 42^{\prime \prime} & \mathrm{S} \\
40^{\circ} 29^{\prime} 55^{\prime \prime} & \mathrm{W}\end{array}$ \\
\hline
\end{tabular}


medium (Vincent, 1970) under aseptic conditions. The plates were incubated at $29^{\circ} \mathrm{C}$ and successive replications were made to obtain pure colonies. The rhizobium characteristics observed were: growth time until the appearance of isolated colonies (rapid: up to 3 days; intermediate: 4 to 5 days and slow: over 6 days), alteration of $\mathrm{pH}$ (acid, neutral and alkaline), size (punctiform, 1-2 $\mathrm{mm}$ and $>2 \mathrm{~mm}$ ), shape (circular or irregular) and color (yellow or white); quantity (few or many), appearance (homogeneous or heterogeneous), elasticity (yes or no) and type of mucus (viscous, butyric and flocular). A binary matrix was constructed from the most pronounced rhizobium characteristics and the isolates were grouped through the UPGMA method based on the Jaccard Index using the NTSYSpc program version 2.1 (Rohlf, 1992). Based on the groups formed, the Shannon-Weaver diversity index (Shannon \& Weaver, 1949), the Margalef richness index (Margalef, 1958) and the Simpson dominance index (Simpson, 1949) were calculated.

DNA extraction, amplification of the 16s rDNA gene and Amplified Ribosomal DNA Restriction Analysis (ARDRA)

To assess the genotypic diversity, 38 representative rhizobium strains from 581 isolates were used, characterized by the colony morphology and growth speed, collected from 2 soils: A1, growing cowpea intercropped with castor bean (Ricinus communis L.) and A4, with irrigated Barbados cherry (Malpighia glabra L), preceded by peanuts (Arachis hypogaea L.) and cowpea. These soils were chosen because they represent different and contrasting land-use systems in the lower half of the São Francisco river valley, namely: A1 is a rain-dependent agriculture area (dry region) without the use of farm inputs (fertilizers and pesticides) and managed with minimum resources (no plowing and harrowing), while the cultural treatments of A4 were mostly conventional, with the application of chemical fertilizers and drip irrigation, representing a system with more intense impacts on soil characteristics. The rhizobium isolates were transferred to plates with YMA culture medium. After growth, a given amount of colony cell mass was transferred to $1.5 \mathrm{~mL}$ microtubes containing $600 \mathrm{iL}$ of TES buffer $\left(0.05 \mathrm{~mol} \mathrm{~L}^{-1} \mathrm{NaCl}, 0.01 \mathrm{~mol} \mathrm{~L}^{-1}\right.$ of Tris $\mathrm{HCl}$ SDS $1 \%, \mathrm{pH} 8$ ) and the DNA extraction procedure followed the protocol proposed by Xavier et al. (2004). Subsequently, the extraction was confirmed in agarose gel at $0.8 \%$.

The PCR reaction was dimensioned for a final volume of $35 \mu \mathrm{L}$ containing $1 \mathrm{X}$ reaction buffer, $\mathrm{MgCl}_{2}$ $1.5 \mu \mathrm{mol} \mathrm{L}^{-1}$, Taq DNA polymerase $1.75 \mathrm{U}$ (Invitrogen cat. No. 11615-010), BSA 0.3 ug $\mu \mathrm{L}^{-1}$, dNTP $250 \mu \mathrm{mol} \mathrm{L}^{-1}$ and $0.2 \mu \mathrm{mol} \mathrm{L}^{-1}$ of each primer. The primers used were Y1, which is between the region $20-43$ of the 16S rDNA gene of $E$. coli and Y3 (Odee et al., 2002), which represents the region $1507-1482$ of the
16S rDNA gene of $E$. coli. The amplification consisted of an initial denaturation step of $93^{\circ} \mathrm{C}$ for $5 \mathrm{~min}$ followed by 35 cycles of $93^{\circ} \mathrm{C}$ for $1 \mathrm{~min}, 62^{\circ} \mathrm{C}$ for $1 \mathrm{~min}$ and $72{ }^{\circ} \mathrm{C}$ for $2 \mathrm{~min}$ and a final extension at $72{ }^{\circ} \mathrm{C}$ for $10 \mathrm{~min}$.

The restriction analysis was carried out with the restriction endonucleases DdeI, MspI and HinfI, using $5 \mu \mathrm{L}$ of amplified DNA according to the manufacturer's recommendations. The digested DNA was analyzed on a horizontal gel at $3 \%$ agarose in $0.5 \%$ TBE buffer for $3 \mathrm{~h}$ at constant $75 \mathrm{~V}$, using the molecular weight marker $\phi X 174$ on the sides of the gel (Invitrogen cat. No.10488-037). The digested DNA fragments were analyzed using the program Gel Compar 2.0 Applied Maths based on the Jaccard coefficient and UPGMA clustering method to construct the similarity dendrogram.

Twenty-two standard strains of diazotrophic bacteria were used (Azorhizobium caulinodans (BR 5410), Azospirillum dobereiner (BR 5401), Bradyrhizobium elkanii (BR 113), Bradyrhizobium japonicum (BR 114), Mesorhizobium ciceri (BR 521), M. huakuii (BR 524), M. loti (BR 7801), M. mediterraneum (BR 522), M. tianshanense (BR 523), Methylobacterium nodulans (BR 2006), Rhizobium etli (BR 10026), R. galegae (BR 10055), R. gallicum (BR 528), R. giardinii (BR 529), R. leguminosarum bv. phaseoli (BR 10052), R. leguminosarum bv. trifolii (BR 7606), R. tropici - IIA (BR 10016), Sinorhizobium fredii (BR 112), S. medicae (BR 525), S. meliloti (BR 7411), S. saheli (BR 526), and S. terangae (BR 527)) obtained from the diazotrophic bacteria collection - Embrapa Agrobiologia.

\section{RESULTS AND DISCUSSION}

\section{Nodulation}

All plants from the five cowpea cultivars developed nodules in all soils studied. In general, the nodulation of the cultivar BRS Pujante was best, while Sempre Verde produced fewest nodules (Table 3). These results showed that, although native cowpea strains have a great nodulation capacity, the nodulation potential of different cultivars may vary greatly. In a recent study comparing cowpea accessions with genetic variability from Brazil, United States and Nigeria, selectivity was observed in the interaction between these accessions and strains used as inoculum (Xavier et al., 2006). This indicates the importance of the plant component in these studies, which is a possible target trait for plant improvement. Seido (2009) evaluated the efficiency of 30 isolates of this study to nodulate and fix $\mathrm{N}_{2}$ to three cowpea cultivars (BRS Marataoã, IPA 206 and BRS Pujante) and verified variability. In this study, BRS Pujante seemed promising for BNF-related studies, for promoting a significant gain in shoot dry matter induced by seven isolates when compared with $\mathrm{N}$ 
control (700 mg/pot of $\mathrm{NH}_{4} \mathrm{NO}_{3}$ ) and absolute control (without characteristics inoculation or mineral $\mathrm{N}$ ). The nodulation caracteristics of these seven isolates in this cultivar was better and efficiency greater in comparison to others. These data reinforce the need for research on $\mathrm{BNF}$ in cowpea based on the plant genotype.

The number of nodules in the soils A3 and MC was higher in all cultivars. Few isolates were obtained from extracts of nodules from soils A2, C1 and MC. These soils had small nodules with a white inner part with no indication of the presence of the leghemoglobin enzyme, characterizing inactive nodules. Although the rhizobium has saprophytic capacity, the presence of the host legume stimulates these populations in the soil, similarly as successive cultivation selects adapted strains (Moreira \& Siqueira, 2006).

\section{Phenotypic characteristics and grouping}

Five hundred and eighty-one isolates with typical rhizobium characteristics were obtained. At least 52 isolates were obtained from each site (Table 4). Of the total number, $62 \%$ (362) formed colonies in up to three days, $33 \%$ (194) grew from the sixth day on and $5 \%$ (25) grew between 4 and 5 days after incubation. This result demonstrates a high population of rapid-growing rhizobium in the soils studied. Martins (1996) reported this feature in $25 \%$ of the isolates from soil samples from Petrolina, from the Sertão (semi-arid region) in the State of Pernambuco, using cowpea as trap plant. This frequency was considered high for the crop, which is usually associated with isolates with typical characteristics of strains from the genus Bradyrhizobium (Martins et al., 1997; Melloni et al., 2006), which in turn comprises, generally, slow-growth strains with ability to alkalinize the culture medium (Santos et al., 2007). The evolution of the incidence of rapid-growth isolates over approximately 15 years, from 25 to $62 \%$, associated with this culture in soils of the lower half of the São Francisco river valley, may be related to climate changes. Analyzing a series of climatic data collected at the agrometeorological station of "Embrapa Semi-Arido" in Petrolina-PE,

Table 3. Nodulation of cowpea cultivars in the lower half of the São Francisco river valley

\begin{tabular}{|c|c|c|c|c|c|c|}
\hline \multirow{2}{*}{ Area } & \multicolumn{5}{|c|}{ Cultivar ${ }^{(1)}$} & \multirow{2}{*}{ Average } \\
\hline & IPA 206 & BRS Pujante & BRS Marataoã & Canapu Roxo & Sempre Verde & \\
\hline & & & Nodules number & & & \\
\hline $\mathrm{A} 1$ & $69.6 \mathrm{cB}$ & $92.2 \mathrm{cA}$ & $58.1 \mathrm{dC}$ & $51.0 \mathrm{eD}$ & $36.0 \mathrm{dE}$ & $61.38 \mathrm{~cd}$ \\
\hline $\mathrm{A} 2$ & $69.3 \mathrm{cB}$ & $93.3 \mathrm{cA}$ & $65.6 \mathrm{cC}$ & $66.0 \mathrm{cC}$ & $47.8 \mathrm{cD}$ & $68.40 \mathrm{bc}$ \\
\hline A3 & $129.5 \mathrm{aC}$ & $183.0 \mathrm{aA}$ & $150.2 \mathrm{aB}$ & $118.2 \mathrm{aD}$ & $76.0 \mathrm{aE}$ & $131.38 \mathrm{a}$ \\
\hline A4 & $26.2 \mathrm{eB}$ & $39.3 \mathrm{eA}$ & $22.3 \mathrm{fC}$ & $21.0 \mathrm{gD}$ & $18.3 \mathrm{eE}$ & $25.42 \mathrm{~d}$ \\
\hline $\mathrm{C} 1$ & $20.4 \mathrm{fC}$ & $37.4 \mathrm{fA}$ & $13.0 \mathrm{gE}$ & $30.0 \mathrm{fB}$ & $17.5 \mathrm{eD}$ & $23.66 \mathrm{~d}$ \\
\hline $\mathrm{C} 2$ & $29.3 \mathrm{dE}$ & $76.1 \mathrm{dA}$ & $41.2 \mathrm{eC}$ & $53.0 \mathrm{~dB}$ & $33.1 \mathrm{dD}$ & $46.54 \mathrm{~cd}$ \\
\hline $\mathrm{MC}$ & $111.1 \mathrm{bB}$ & $156.5 \mathrm{bA}$ & $85.0 \mathrm{bD}$ & $100.0 \mathrm{bC}$ & $57.7 \mathrm{bE}$ & $102.06 \mathrm{ab}$ \\
\hline Average & $65.06 \mathrm{~b}$ & $96.83 \mathrm{a}$ & $62.2 \mathrm{bc}$ & $62.74 \mathrm{bc}$ & $40.91 \mathrm{~d}$ & - \\
\hline CV (\%) & 29.21 & 20.86 & 39.16 & 24.8 & 30.76 & - \\
\hline
\end{tabular}

(1) Means followed by different letters - lower-case letters in columns and capital letters in rows - differ from each other by the Tukey test at $5 \%$.

Table 4. Number of rhizobium isolates obtained from cowpea grown in soils of the lower half of the São Francisco River valley

\begin{tabular}{|c|c|c|c|c|c|c|}
\hline \multirow{2}{*}{ Area } & \multicolumn{5}{|c|}{ Cultivar } & \multirow{2}{*}{ Total } \\
\hline & IPA 206 & BRS Pujante & BRS Marataoã & Canapu roxo & Sempre verde & \\
\hline $\mathrm{A} 1$ & 14 & 21 & 29 & 18 & 23 & 105 \\
\hline $\mathrm{A} 2$ & 9 & 10 & 12 & 8 & 16 & 55 \\
\hline A3 & 10 & 28 & 27 & 26 & 32 & 123 \\
\hline $\mathrm{A} 4$ & 28 & 20 & 23 & 18 & 10 & 99 \\
\hline $\mathrm{C} 1$ & 8 & 18 & 5 & 10 & 11 & 52 \\
\hline $\mathrm{C} 2$ & 12 & 21 & 20 & 19 & 17 & 89 \\
\hline $\mathrm{MC}$ & 7 & 14 & 17 & 13 & 7 & 58 \\
\hline Total & 88 & 132 & 133 & 112 & 116 & 581 \\
\hline
\end{tabular}


Angelotti (2008) observed positive changes due to the temperature of this region. According to Sprent (1994), rapid-growth rhizobium are common in arid and semiarid regions, and this feature is a survival strategy, since they are more tolerant to drought than those of slow growth, multiplying rapidly in a short period of time (Santos et al., 2007). Regarding the formation of acid and alkali, $63 \%$ acidified the culture medium, $12 \%$ alkalinized it and $25 \%$ maintained the medium $\mathrm{pH}$ neutral.

Except for A3, all areas showed a higher occurrence of rapid-growing isolates, with minimum frequency of $51 \%$ in A1 (Figure 1-A1). This predominance of rapid-growing isolates contrasts with the current knowledge that cowpea-nodulating rhizobium belong to the genus Bradyrhizobium spp, as mentioned previously.

Over $80 \%$ of the isolates of soil A3 formed colonies after six days of incubation. This distinction in relation to other soils in the growth pattern may be related to the $\mathrm{pH} 8.0$ in the area, resulting in a more favorable environment for slow-growing rhizobium, under conditions of alkaline $\mathrm{pH}$ (Saleena et al., 2001). Acid reaction of $\mathrm{pH}$ in the culture medium was expressed by $28 \%$ of the isolates from this soil (Figure 1-B1). According to Figueiredo et al. (1996), the occurrence of slow or fast growing rhizobium seems to be related to the soil $\mathrm{pH}$. Anyango et al. (1995) reported that the predominant rhizobum types in soils with different $\mathrm{pH}$ ranges can differ. Comparable to temperature, the soil $\mathrm{pH}$ is a determining factor for the success of the rhizobium strain in promoting efficient nodulation in associated legumes (Neves \& Rumjanek, 1998). According to Martins (1996), it is possible that the ability of rhizobium to alkalinize the medium represents a selective advantage. For the host, this characteristic was similar in all cultivars tested (Figure 1-A2).

The reaction of $\mathrm{pH}$ in the culture medium also differed between A3 and the other soil types (Figure 1B1); A3 was the soil with the highest frequency of isolates with alkaline reaction in YMA medium. Similarly to the growth speed characteristics, the cultivars did not show different behavior for the frequency of associated rhizobium in relation to the $\mathrm{pH}$ reaction in the medium (Figure 1-B2).

The isolates were grouped according to the characteristics that most differentiated: growth time, $\mathrm{pH}$ of the medium, size, color and quantity of mucus. This group formed 49 morphological groups at the level of $100 \%$ similarity, according to the Jaccard index and a dendrogram based on the UPGMA grouping method (Table 4), with 18 groups with rapid growth, 10 groups of intermediate growth and 21 groups of slow growth characteristics. The number of groups formed shows that slow-growth strains, although less frequent (33\%), are more diverse with respect to the morphology of colonies in the soils studied by forming the largest number of morphological groups. The groups G5 (23.7 \%) and G1 (14\%) were the most abundant. Both groups presented typical characteristics of genera Rhizobium,
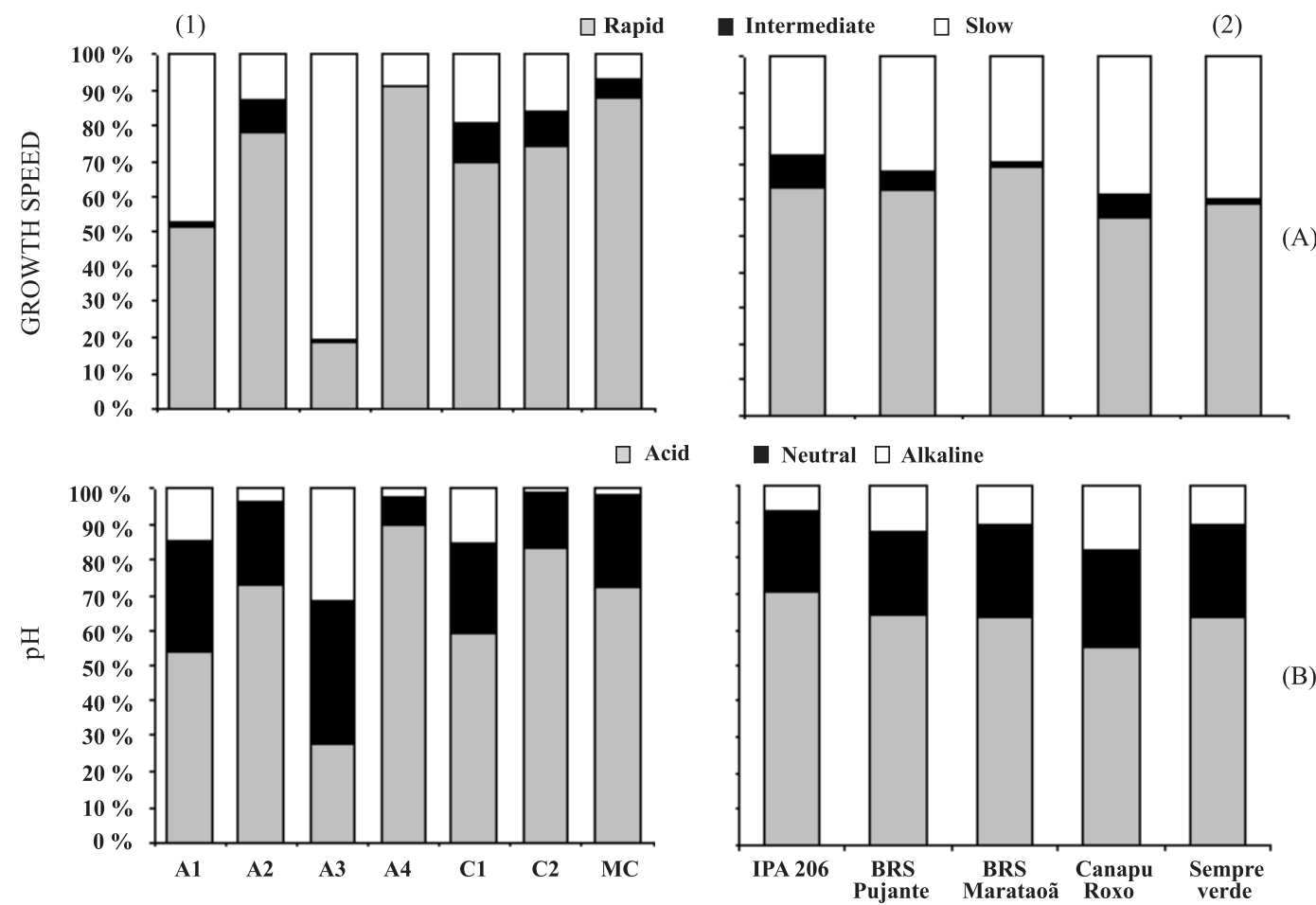

Figure 1. Rhizobium frequency in relation to the growth speed (A) and to the pH reaction (B) according to the origin (1) and cowpea cultivar associated (2). 
Table 5. Morphological groups based on the rhizobium characteristics growth speed, pH in the culture medium, size and color of the colony and the quantity of mucus of cowpea rhizobium isolates grown in soils of the lower half of the São Francisco river valley

\begin{tabular}{|c|c|c|c|c|c|c|}
\hline Group & Number of isolates & Growth time & Medium pH & Colony size & Colony color & Quantity of mucus \\
\hline & & & & $\mathrm{mm}$ & & \\
\hline G1 & 83 & Rapid & Acid & $>2$ & Yellow & Many \\
\hline $\mathrm{G} 2$ & 8 & Rapid & Acid & $>2$ & Yellow & Few \\
\hline G3 & 1 & Slow & Acid & $>2$ & Yellow & Many \\
\hline $\mathrm{G} 4$ & 25 & Rapid & Acid & $>2$ & White & Many \\
\hline G5 & 138 & Rapid & Acid & 1 to 2 & Yellow & Many \\
\hline G6 & 27 & Rapid & Acid & 1 to 2 & Yellow & Few \\
\hline G7 & 10 & Rapid & Neutral & 1 to 2 & Yellow & Many \\
\hline G8 & 14 & Slow & Acid & 1 to 2 & Yellow & Many \\
\hline G9 & 2 & Slow & Acid & 1 to 2 & Yellow & Few \\
\hline G10 & 5 & Slow & Neutral & 1 to 2 & Yellow & Many \\
\hline G11 & 2 & Slow & Alkaline & 1 to 2 & Yellow & Many \\
\hline G12 & 5 & Inte rmediate & Acid & 1 to 2 & Yellow & Few \\
\hline G13 & 8 & Intermediate & Acid & 1 to 2 & Yellow & Many \\
\hline G14 & 2 & Intermediate & Acid & $>2$ & Yellow & Many \\
\hline G15 & 2 & Intermediate & Acid & $>2$ & White & Many \\
\hline G16 & 2 & Rapid & Acid & Punctinfom & White & Few \\
\hline G17 & 10 & Rapid & Acid & 1 to 2 & White & Few \\
\hline G18 & 7 & Rapid & Acid & $>2$ & White & Few \\
\hline G19 & 1 & Intermediate & Acid & $>2$ & White & Few \\
\hline $\mathrm{G} 20$ & 1 & Slow & Acid & $>2$ & White & Few \\
\hline $\mathrm{G} 21$ & 3 & Rapid & Acid & Punctinfom & Yellow & Few \\
\hline G22 & 1 & Slow & Acid & Punctinfom & Yellow & Few \\
\hline $\mathrm{G} 23$ & 2 & Slow & Neutral & 1 to 2 & Yellow & Few \\
\hline $\mathrm{G} 24$ & 3 & Slow & Neutral & 1 to 2 & Yellow & Few \\
\hline $\mathrm{G} 25$ & 1 & Rapid & Neutral & $>2$ & Yellow & Few \\
\hline G26 & 1 & Slow & Alkaline & $>2$ & Yellow & Few \\
\hline $\mathrm{G} 27$ & 21 & Rapid & Alkaline & 1 to 2 & White & Few \\
\hline $\mathrm{G} 28$ & 27 & Slow & Neutral & 1 to 2 & White & Few \\
\hline G29 & 3 & Slow & Acid & 1 to 2 & White & Few \\
\hline G30 & 1 & Intermediate & Neutral & 1 to 2 & White & Few \\
\hline G31 & 12 & Rapid & Neutral & 1 to 2 & White & Few \\
\hline G32 & 3 & Slow & Alkaline & Punctinfom & White & Few \\
\hline G33 & 2 & Intermediate & Neutral & Punctinfom & White & Few \\
\hline G34 & 4 & Slow & Neutral & Punctinfom & White & Few \\
\hline G35 & 35 & Slow & Neutral & 1 to 2 & White & Many \\
\hline G36 & 39 & Slow & Alkaline & 1 to 2 & White & Many \\
\hline G37 & 10 & Slow & Acid & 1 to 2 & White & Many \\
\hline G38 & 2 & Intermediate & Neutral & 1 to 2 & White & Many \\
\hline G39 & 11 & Rapid & Acid & 1 to 2 & White & Many \\
\hline G40 & 10 & Rapid & Neutral & 1 to 2 & White & Many \\
\hline G41 & 12 & Slow & Neutral & $>2$ & White & Many \\
\hline G42 & 1 & Intermediate & Neutral & $>2$ & White & Many \\
\hline G43 & 3 & Slow & Alkaline & $>2$ & White & Many \\
\hline G44 & 2 & Slow & Acid & $>2$ & White & Many \\
\hline G45 & 8 & Rapid & Neutral & $>2$ & White & Many \\
\hline G46 & 4 & Rapid & Neutral & $>2$ & Yellow & Many \\
\hline G47 & 2 & Rapid & Neutral & $>2$ & White & Few \\
\hline G48 & 4 & Slow & Neutral & $>2$ & White & Few \\
\hline G49 & 1 & Intermediate & Neutral & $>2$ & White & Few \\
\hline
\end{tabular}

Mesorhizobium and Sinorhizobium in terms of growth speed (rapid) and pH reaction (acid). Group G36 (6.7\%) was formed by slow-growing isolates that alkalinize the culture medium. This characteristic is common to the genera Bradyrhizobium and Azorhizobium. Of all groups, 18 were rare, containing 1 or 2 isolates. 
Exclusive morphological groups were associated with different cultivars; with the exception of BRS Marataoã, which presented no associated exclusive group. Groups G11, G20, G22, G42, G46, and G49 were related only to cultivar Canapu Roxo. Isolates that formed groups G14, G19, G26, G30, and G47 were obtained from nodules from BRS Pujante cultivar. In these cultivars more associated morphological groups were found, indicating the ability of these genotypes to nodulate a higher number of morphological types in the soils studied, compared to other cultivars tested. Cultivars IPA 206 and Sempre Verde had, respectively, two (G3 and G38) and one (G25) exclusive groups. These results suggest a possible discriminatory effect of cowpea genotypes in the associated rhizobium community, even though the host specificity of cowpea is low. However, studies with cross inoculation between exclusive groups and cultivars are needed to confirm these results. Xavier et al. (2006) studied the nodule occupation rate by rhizobium strains on cowpea and verified symbiotic specificity of rhizobium strains from Northeastern Brazil and cowpea accessions from three countries (Brazil, USA and Nigeria). The distribution pattern of isolates on each cultivar, according to the morphological groups, can be seen in figure 2 . Isolates from cultivar IPA 206 are distributed into 22 groups, with the highest percentages found in G5, G1 and G35. In the cultivar BRS Pujante, the isolates were distributed into 32 groups, with the highest percentages found in groups G5, G1, G35 and G36. The 133 strains isolated from BRS Marataoã are distributed into 27 groups, and G5, G1, G6 and G28 were the most abundant in this cultivar. On Canapu Roxo, the isolates were distributed into 32 groups; however, the highest percentages were found in groups G5, G4, G36 and G28. Finally, on the Sempre Verde cultivar, the highest frequencies were observed for the groups G5, G1, G35, and G4.

\section{Diversity indexes}

The Shannon-Weaver diversity index, Margalef richness index and Simpson dominance index were calculated for morphological groups present in soil and associated with the cultivars studied (Table 6). The calculations showed higher diversity and richness indexes in an area under organic maize production system intercropped with cowpea (A3), while the
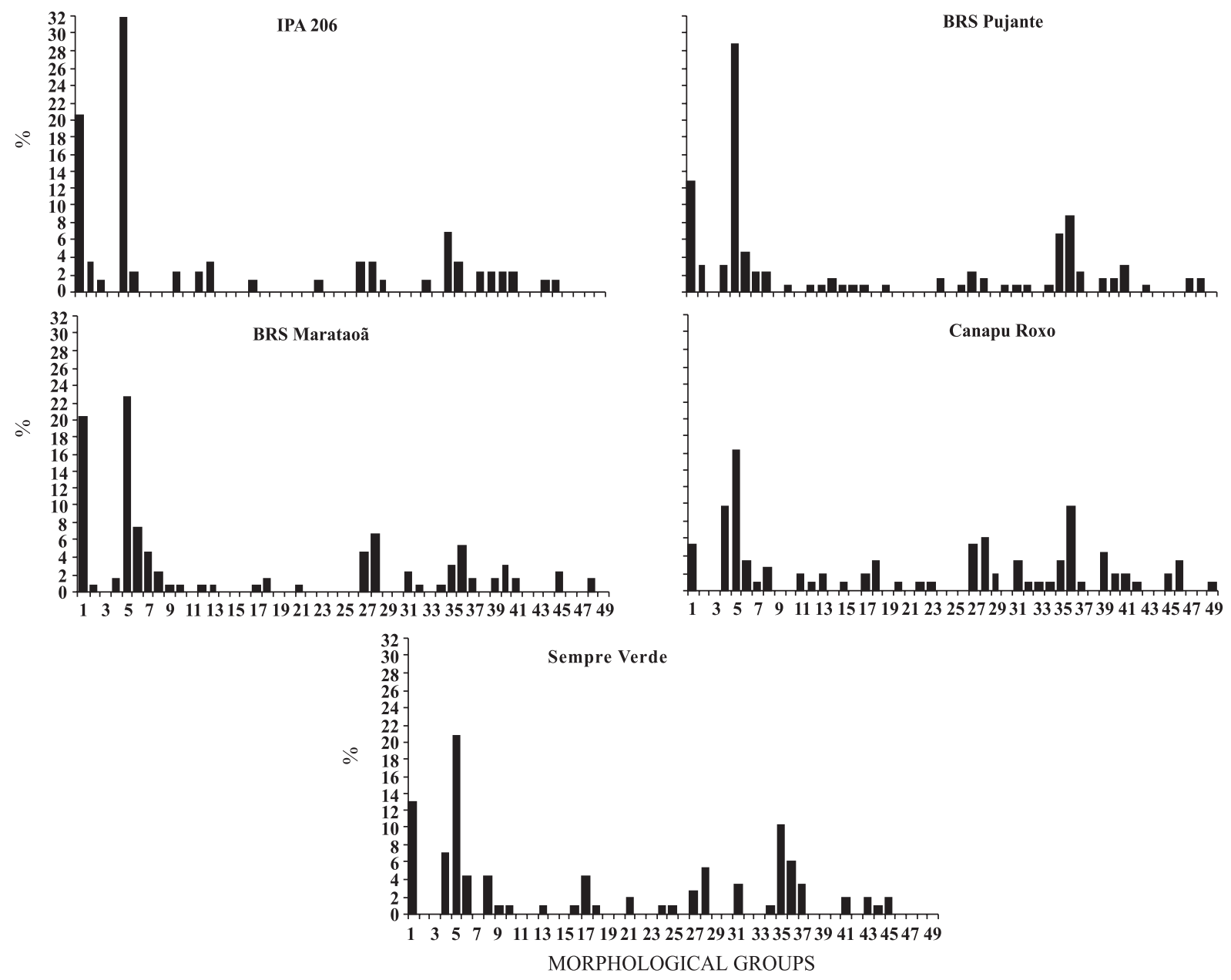

Figure 2. Frequency of rhizobium groups in cowpea cultivars grown in soils of the lower half of the São Francisco river valley. 
diversity index in the area under irrigated cultivation of Barbados cherry (A4) was lower. According to Zilli (2001), the presence of leguminous plants influenced the rhizobiuml population and may be indicated as the most important factor for the composition of this group of microorganisms. The benefits in the soil microbiota generated by organic production systems have been extensively reported in the literature (Altiere, 1999; Ehlers, 1999; Gleisman, 2000).

With the exception of A3, the diversity indexes in $\mathrm{MC}$ and $\mathrm{C} 1$ were than in the crop areas. These two areas are characterized by native vegetation with higher diversity of shrub and arborous leguminous species than the other areas studied, showing a correlation between plant diversity and soil microbial diversity. The dominance indexes were highest in the areas A4 and A1. Santos et al. (2007) agrees with the idea that the semi-arid region of Northeastern Brazil (Sertão), including the lower half of the São Francisco river valley, has peculiar features, where the entire biodiversity is under constant stress conditions, of either high temperature or low rainfall levels. These conditions, according to these authors, can affect rhizobium survival and effectiveness in this region and it is possible that the high diversity observed is an indication that the system is able to maintain the functional group even under stress conditions.

Among the cultivars, a different behavior was observed for the diversity, richness and dominance indexes values calculated. The cultivars Canapu Roxo and BRS Pujante had higher Shannon - Weaver diversity and Margalef richness indexes. Cultivar Canapu Roxo showed richness index $40 \%$ higher than IPA 206, cultivar with lower index. Santos et. al. (2007) studied soils from Pernambuco and found different behavior regarding the richness of rhizobium isolated of nine peanut cultivars. In general, the Simpson dominance values areas were lower for cultivars with higher rhizobium diversity.

Table 6. Shannon-Weaver diversity, Margalef richness and Simpson dominance indexes of rhizobium isolated from five cowpea cultivars in soils of the lower half of the São Francisco river valley

\begin{tabular}{lccc}
\hline Origin/cultivar & Shanno-Weaver & Margalef & Simpson \\
\hline Origin & & & \\
A1 & 3.17 & 3.44 & 0.17 \\
A2 & 3.50 & 4.74 & 0.14 \\
A3 & 3.88 & 5.03 & 0.10 \\
A4 & 2.47 & 3.47 & 0.29 \\
C1 & 3.85 & 4.43 & 0.09 \\
C2 & 3.35 & 4.93 & 0.15 \\
MC & 3.87 & 4.45 & 0.08 \\
& & & \\
Cultivar & & & \\
IPA 206 & 3.47 & 4.69 & 0.16 \\
BRS Pujante & 3.94 & 6.39 & 0.12 \\
BRS Marataoã & 3.82 & 5.32 & 0.11 \\
Canapu Roxo & 4.38 & 6.56 & 0.07 \\
Sempre Verde & 3.90 & 4.86 & 0.09 \\
\hline
\end{tabular}

\section{Amplified Ribosomal DNA Restriction Analysis (ARDRA)}

The restriction profiles of the $16 \mathrm{~S}$ rDNA of 38 isolates and standard strains digested with the enzymes DdeI, HinfI and MspI generated four main groups (Figure 3). A high diversity level was found between isolates determined by the low final similarity level of the groups formed ( $22 \%)$. The groups formed had between $26 \%$ (group D) and $48 \%$ (group C) of similarity. Genetic differences between rhizobium isolates using ARDRA were also observed by Han et al. (2008), Stocco et al. (2008), Ruiz-Díez et al. (2009) and Sui et al. (2009).

Group A, with $30 \%$ similarity between members of the group had only one isolate from area A4 and very low similarity (36\%) with strain BR 2006 of Methylobacterium nodulans. This genus contains only one rhizobium strain described by Weir (2008). This group included strains BR 5401 and BR 5410. B was composed of 13 isolates and all standard rhizobium strains used in this study. Although these isolates, along with rhizobium standards, formed a group with $40 \%$ similarity, an influence of the origin of the isolates on the formation of subgroups was observed. Subgroup B1, with $54 \%$ similarity, contained only isolates from area A4, where irrigation and fertilizers were applied. Subgroup B2, with $62 \%$ similarity, consisted of isolates from area A1. The electrophoretic profile of four isolates of this subgroup (111-3, 121-2, 211-1, 512-3) showed $100 \%$ similarity, indicating the possibility of being the same species. The three enzymes could not differentiate the strain Rhizobium etli (BR 10026) from R. leguminosarum bv. phaseoli (BR 10052), or R. leguminosarum bv. trifolii (BR 7606) from R. gallicum (BR 528), which appeared in this group with $100 \%$ similarity between them. Studying the biodiversity of bean symbiont rhizobium, Stocco et al. (2008) also found no distinction between $R$. leguminosarum and $R$. giardinii using three enzymes (HhaI, HpaII and RsaI). The strains $R$. galegae (BR 10055) and $R$. giardinii (BR 529) and isolate 373-6 appeared isolated in this group, with similarities of 42 and $40 \%$, respectively, with the two subgroups formed.

In group $\mathrm{C}$, divided into two subgroups $(\mathrm{C} 1$ and C2), 11 isolates were included. In subgroup $\mathrm{C} 1$, nine isolates from area $\mathrm{A} 1$ and two from area $\mathrm{A} 4$ were grouped. Isolates 113-2, 113-3 and 112-1 showed similar restriction profiles of $16 \mathrm{~S}$ rDNA (100\% similarity). In this group, the standard strains of Bradyrhizobium elkanii (BR 2811) and Bradyrhizobium japonicum (BR 114) were included, both with $70 \%$ similarity with isolate 471-2. In turn, $\mathrm{C}_{2}$ was formed by all standard strains of Mesorhizobium and Sinorhizobium used in this study with $52 \%$ similarity with subgroup C1. The strains Sinorhizobium medicae (BR 525) and Sinorhizobium meliloti (BR 7411), as well as Sinorhizobium terangae (BR 527) and Sinorhizobium saheli (BR526) showed $100 \%$ similarity, and 


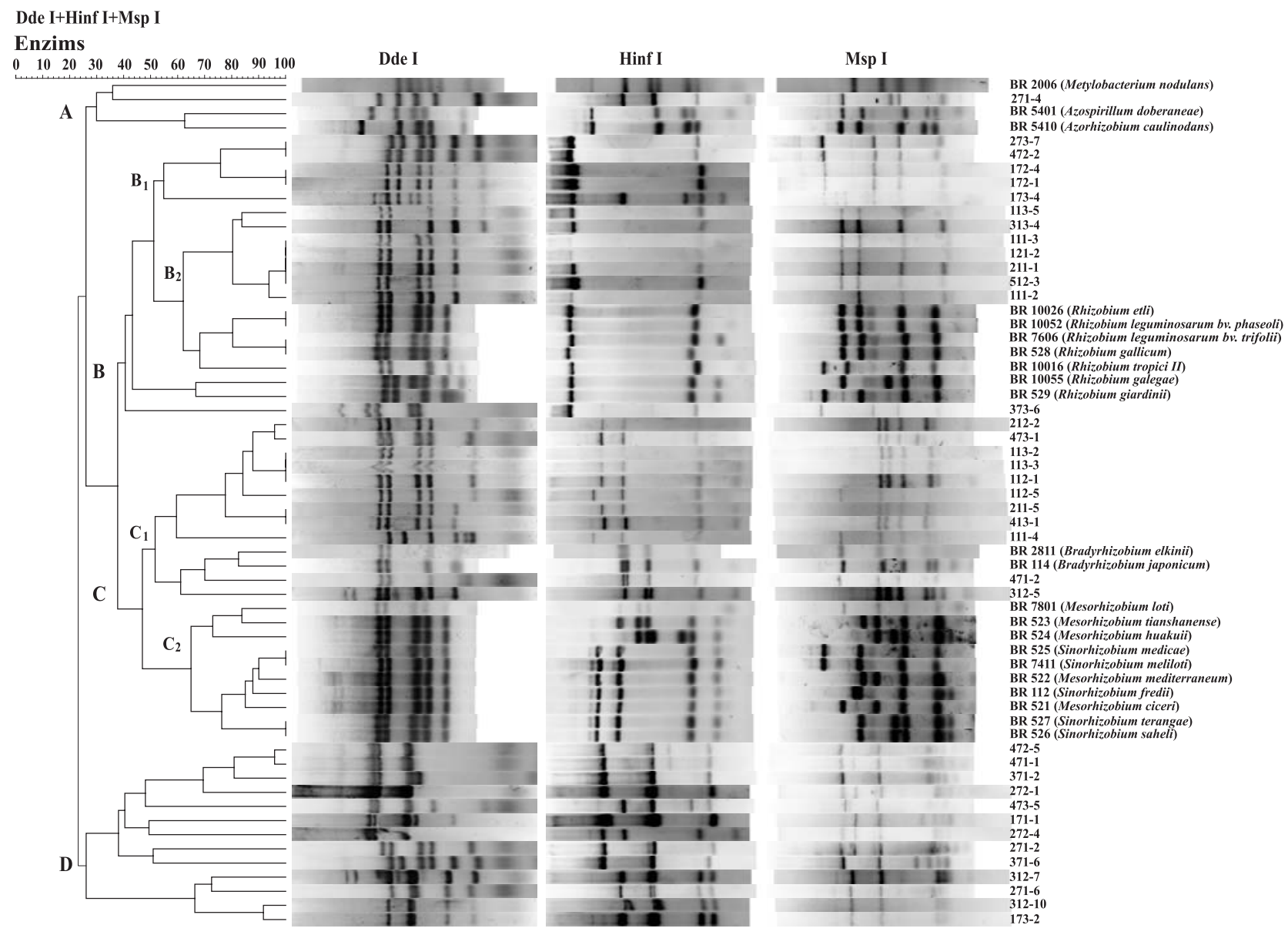

Figure 3. Composite dendrogram of cowpea isolates from two soil samples and rhizobium strains cleaved with the restriction enzymes DdeI, HinfI and MspI.

differences between these strains and the three restriction enzymes used were not revealed. For group $\mathrm{D}$, in contrast with group $\mathrm{C}$, a predominance of isolates from area A4 was reported. Eleven out of the 13 isolates included in this group were from this area. No standard strain was included in this group, which showed low similarity (24\%) with the standard strains, and a quite different electrophoretic profile from standard rhizobium.

Lima et al. (2005) studied isolates from Bradyrhizobium in different land use systems (LUS) in the Amazon region and found no correlation between the profile of total proteins determined in SDS-PAGE gel, and the origin of isolates. This study showed a strong tendency of isolates from the same area to group together, suggesting that the ARDRA analysis may be an appropriate tool for studies of geographical distribution of rhizobiuml populations. Shamseldin et al. (2009) used ARDRA to study rhizobium populations in soils from different provinces of Egypt. These authors showed rhizobium genotypes scattered in the different areas studied, while a particular genotype was found predominantly in one specific area.
Finally, the electrophoretic profiles of group $\mathrm{D}$ and subgroups $\mathrm{B}_{1}$ and $\mathrm{C}_{1}$ were quite different from all standard rhizobium strains used in this study. The data suggest a wide diversity of rhizobium existing in soil samples from the lower half of the São Francisco river valley, representing a promising source of genetic resources.

\section{CONCLUSIONS}

1. The number of exclusive groups of BRS Pujante and Canapu Roxo was high, indicating these cultivars for rhizobium diversity studies.

2 . The highest diversity and richness indexes were found in the area under organic maize intercropped with cowpea.

3. Thirteen rhizobium isolates (group D) presented distinct electrophoretic profile when compared to rhizobium standard strains used in this study. 


\section{ACKNOWLEDGEMENTS}

The authors wish to thank the MCT / National Council of Scientific and Technological Development (CNPq), Departamento de Ciência e Tecnologia/ Ministério da Saúde (DECIT / MS), Fund of Biotechnology (CT-BIOTECNOLOGIA) and Fund of Health (CT-SAÚDE) for funding the project in the scope of the Rede Nordeste de Biotecnologia (RENORBIO), the CNPq for the scholarships in Technological and Industrial Initiation and award for Excellence in Research and they are grateful to Dr Robert Boddey for reading the manuscript.

\section{LITERATURE CITED}

ALTIERI, M.A. The ecological role of biodiversity in agroecosystems. Agric. Ecosyst. Environ., 74:19-31, 1999.

ANGELOTTI, F. Mudanças climáticas e suas interferências na agropecuária e nos recursos hídricos e sócioeconômicos. In: SIMPÓSIO SOBRE MUDANÇAS CLIMÁTICAS E DESERTIFICAÇÃO NO SEMI-ÁRIDO BRASILEIRO, 1., Petrolina, 2008. Simpósio...Petrolina, Embrapa Semi-Árido, 2008.

ANYANGO, B.; WILSON, K.J.; BEYNON, J.L. \& GILLER, K.E. Diversity of rhizobia nodulating Phaseolus vulgaris L. in two Kenyan soils with contrasting pHs. Appl. Environ. Microbiol., 61:4016-4021, 1995.

EHLERS, E. Agricultura sustentável: Origens e perspectivas de um novo paradigma. 2.ed. Guaíba, Agropecuária, 1999. $157 \mathrm{p}$.

EMPRESA BRASILEIRA DE PESQUISA AGROPECUÁRIA EMBRAPA. Centro Nacional de Pesquisa de Solos. Manual de métodos de análises de solos. 2.ed. Rio de Janeiro, Embrapa Solos, 1997. 212p.

FIGUEIREDO, M.V.B.; STAMFORD, N.P.; SANTOS; C.E.R.S. \& MEDEIROS, R. Efeito da adubação com diferentes relações de potássio/magnésio no Jacatupé em Latossolo Amarelo com e sem inoculação de Bradyrhizobium sp. R. Bras. Ci. Solo, 20:49-54, 1996.

FIGUEIREDO, M.V.B.; BURITY, H.A.; STAMFORD, N.P. \& SANTOS, C.E.R.S. Microrganismos e agrobiodiversidade: O novo desafio para a agricultura. Guaíba, Agrolivros, 2008. 568 p.

FREIRE FILHO, F.R.; LIMA, J.A.A. \& RIBEIRO, V.Q., eds. Feijão-caupi: Avanços tecnológicos. Brasília, Embrapa Informação Tecnológica, 2005. 519p.

GLIESSMAN, S.R. Agroecologia: Processos ecológicos em agricultura sustentável. 2.ed. Porto Alegre, Universidade Federal do Rio Grande do Sul, 2000. 653p.

HAN, T.X.; WANG, E.T.; HAN, L.L.; CHEN, W.F.; SUI, X.H. \& CHEN, W.X. Molecular diversity and phylogeny of rhizobia associated with wild legumes native to Xinjiang, China. Syst. Appl. Microbiol., 31:287-301, 2008.
LIMA, A.S.; PEREIRA, J.P.A.R. \& MOREIRA, F.M.S. Diversidade fenotípica e eficiência simbiótica de estirpes de Bradyrhizobium spp. de solos da Amazônia. Pesq. Agropec. Bras., 40:1095-1104, 2005.

MARGALEF, R. Temporal succession. In: POZZA, T. \& TRAVES, M. Perspective marine biology. Berkeley, University of California, 1958. p.323-347.

MARTINS, L.M.V.; XAVIER, G.R.; RANGEL, F.W.; RIBEIRO, J.R.A.; NEVES, M.C.P.; MORGADO, L.B. \& RUMJANEK, N.G. Contribution of biological nitrogen fixation to cowpea: A strategy for improving grain yield in the semi-arid region of Brazil. Biol Fert. Soils, 38:333-339, 2003.

MARTINS, L.M.V.; NEVES, M.C.P. \& RUMJANEK, N.G. Growth characteristics and symbiotic efficiency of rhizobia isolated from cowpea nodules of the north-east Region of Brazil. Soil Biol. Biochem., 29:1005-1010, 1997.

MARTINS, L.M.V. Características ecológicas e fisiológicas de rizóbio de feijão-caupi (Vinga unguiculata (L.) Walp) isolados a partir de solos da região Nordeste do Brasil. Seropédica, Universidade Federal Rural do Rio de Janeiro, 1996. 213p. (Tese de Mestrado)

MELLONI, R.; MOREIRA, F.M.S.; NÓBREGA, R.S.A. \& SIQUEIRA, J.O. Eficiência e diversidade fenotípica de bactérias diazotróficas que nodulam caupi [Vigna unguiculata (L.) Walp] e feijoeiro (Phaseolus vulgaris L.) em solos de mineração de bauxita em reabilitação. R. Bras. Ci. Solo, 30:235-246, 2006.

MOREIRA, F.M.S. \& SIQUEIRA, J.O. Microbiologia e bioquímica do solo. Lavras, Universidade Federal de Lavras, 2006. 729p.

NEVES, M.C.P. \& RUMJANEK, N.G. Ecologia das bactérias diazotróficas nos solos tropicais. In: MELO, I.S. \& AZEVEDO, J.L., eds. Ecologia microbiana. Jaguariúna, Embrapa- CNPMA, 1998. p. 15-60.

ODEE, D.W.; HAUKKA, K.; MCINROY, S.G.; SPRENT, J.I.; SUTHERLAND, J.M. \& YOUNG, J.P.W. Genetic and symbiotic characterization of rhizobia isolated from tree and herbaceous legumes grown in soils from ecologically diverse sites in Kenya. Soil Biol. Biochem., 34:801-811, 2002.

ROHLF, J.F. NTSYS-pc: Numerical taxonomy and multivariate analysis system: version 1.70. New York, Applied Biostatistics, 1992

RUIZ-DÍEZ, B.; FAJARDO, S.; PUERTAS-MEJÍA, M.A.; FELIPE, M.R. \& FERNÁNDEZ-PASCUAL, M. Stress tolerance, genetic analysis and symbiotic properties of root-nodulating bacteria isolated from Mediterranean leguminous shrubs in Central Spain. Arch. Microbiol., 191:35-46, 2009.

SALEENA, L.M.; LOGANATHAN, P.; RANGARAJAN, S. \& NAIR, S. Genetic diversity of Bradyrhizobium strains isolated from Arachis hypogaea. Canadian. J. Microbiol., 47:118-122, 2001. 
SANTOS, C.E.R.E.S.; STAMFORD, N.P.; NEVES, M.C.P.; RUMJANEK, N.G.; WARDSON, L.B.; BEZERRA, R.V. \& FREITAS, A.D.S. Diversidade de rizóbios capazes de nodular leguminosas tropicais. R. Bras. Ci. Agrar., 2:249. 256, 2007.

SEIDO, S.L. Validação de isolados de rizóbio obtidos de solos da região do submédio São Francisco associados a três cultivares de feijão-caupi. Juazeiro, DTCS/UNEB, 2009. 35p. (Monografia de Graduação)

SHAMSELDIN, A.; EL-SAADANI, M.; SADOWSKY, M.J. \& AN, C.S. Rapid identification and discrimination among Egyptian genotypes of Rhizobium leguminosarum bv. viciae and Sinorhizobium meliloti nodulating faba bean (Vicia faba L.) by analysis of nodC, ARDRA, and rDNA sequence analysis. Soil Biol. Biochem, 41:45-53, 2009.

SHANNON, C.E. \& WEAVER, W. The mathematical theory of communication. Urbana, University Illinois Press, 1949.

SIMPSON, E.H. Measurement of diversity. Nature, 163: 688$688,1949$.

SPRENT, J.I. Evolution and diversity in the legume-rhizobium symbiosis: Chaos - theory? Plant Soil, 161:1-10, 1994.

STOCCO, P.; SANTOS, J.C.P.; VARGAS, V.P. \& HUNGRIA, M. Avaliação da biodiversidade de rizóbios simbiontes do feijoeiro (Phaseolus vulgaris L.) em Santa Catarina. R. Bras. Ci. Solo, 32:1107-1120, 2008.
SUI, X.H.; HAN, L.L.; WANG, E.T.; JIANG, F.; LIU, Y.H. \& CHEN, W.X. Novel associations between rhizobial populations and legume species within the genera Lathyrus and Oxytropis grown in the temperate region of China. Sci. China Ser. C-Life Sci., 52:182-192, 2009.

VINCENT, J.M. A manual for the practical study of rootnodule bacteria. London, International Biological Programme, 1970. 164p. (Handbook, 15)

WEIR, B.S. The current taxonomy of rhizobia [Last updated: 16th November, 2008]. Disponível em: <http:// www.rhizobia.co.nz/taxonomy/rhizobia.html>. Acessado em: 20 abr. de 2009.

XAVIER, G.R.; MARTINS, L.M.V.; RIBEIRO, J.R.A. \& RUMJANEK, N.G. Especificidade simbiótica entre rizóbios e acessos de feijão-caupi de diferentes nacionalidades. Caatinga, 19:25-33, 2006.

XAVIER, G.R.; SILVA, F.V.; ZILLI, J.E. \& RUMJANEK, N.G. Adaptação de método para extração de DNA de microrganismos associados a raízes de plantas. Seropédica, Embrapa Agrobiologia, 2004. 24p. (Embrapa Agrobiologia. Documentos, 171)

ZILLI, J.E. Caracterização e seleção de estirpes de rizóbio para a inoculação de caupi (Vigna unguiculata (L.) Walp.) em áreas de Cerrado. Seropédica, Universidade Federal Rural do Rio de Janeiro, 2001. 112p. (Tese de Mestrado) 